\title{
PENGARUH SANKSI, REWARD DAN \\ PENGEMBANGAN SUMBER DAYA MANUSIA \\ TERHADAP DISIPLIN KERJA PEGAWAI \\ PADA DINAS PEKERJAAN UMUM DAN \\ PENATAAN RUANG KABUPATEN \\ DHARMASRAYA
}

\author{
Mega Meri Mustika, Febsri Susanti \\ Sekolah Tinggi Ilmu Ekonomi "KBP" \\ febsrisusanti@akbpstie.ac.id
}

\begin{abstract}
In this study aims to give an idea of how the effects of sanctions, rewards and human resource development on employee work discipline Department of Public Works and Spatial Planning Dharmasraya Regency.The variables described in the study are sanctions (X1), reward (X2), human resource development $(X 3)$ and work discipline $(Y)$. the hypothesis described by the researcher is 1) the influence of sanction on work discipline, 2) the influence of reward on work discipline and 3) the influence of human resource development on work discipline. Based on the results of the study then the authors to get the conclusion which between sanctions and rewards are both significant and positive influence on the discipline of work while for the development of human resources researchers get negative results and insignificant to the discipline of employment
\end{abstract}

Keywords: sanction, reward, human resource development and work discipline

\section{PENDAHULUAN}

Semua organisasi atau perusahaan pasti mempunyai standar perilaku yang harus dilakukan dalam hubungannya dengan pekerjaan. Baik secara tertulis maupun tidak, dan menginginkan para pegawai untuk mematuhinya sebagai upaya untuk meningkatkan produktifitas. Tetapi pada kenyataannya, sebagai manusia biasa pegawai mempunyai kelemahan yaitu kedisiplinan.

Disiplin merupakan suatu proses yang dapat menumbuhkan perasaan seseorang untuk mempertahankan dan meningkatkan tujuan organisasi secara obyektif, melalui kepatuhannya menjalankan peraturan organisasi (Slamet, 2007). Kesadaran adalah sikap seseorang yang secara sukarela mentaati semua peraturan dan sekedar akan tugas dan tanggung jawab. Jadi, dia akan mematuhi dan mengerjakan semua tugasnya dengan baik, bukan atas paksaan, Hasibuan (2009:193). 
Kantor Dinas Pekerjaan umum dan penataan ruang adalah suatu dinas pemerintah yang mempunyai fungsi dan tugas, dimana fungsi tersebut meliputi: perumusan kebijakan dinas, penyusunan rencana stratejik dinas, penyelenggaraan pelayanan umum, penataan ruang, dan kebersihan. Pembinaan, pengkoordinasian, pengendalian, pengawasan. Demikian pula setiap orang berdisiplin sudah tidak mustahil, baik dalam instansi atau organisasi dimana mereka bekerja akan memperlihatkan suatu organisasi dengan iklim yang sehat, yang kuat dengan prestasi yang dapat dihandalkan. Pada Kantor Dinas Pekerjaan Umum dan Penataan Ruang di kabupaten Dharmasraya dalam menegakkan kedisiplinan bagi para pegawai yaitu dengan cara menetapkan peraturan tentang disiplin agar pegawai mampu menjalankan tugas dan kewajiban sesuai dengan standar tingkat keterlambatan $5 \%$ dan tingkat kemangkiran $2 \%$.

Berdasarkan hasil prasurvey menunjukkan bahwa dari tiga variabel yang diajukan yaitu sanksi, reward, dan pengembangan sumber daya manusia melalui indikator terbanyak dari masing- masing variabel, dapat diketahui bahwa $80 \%$ responden menyatakan bahwa pegawai mendapatkan teguran secara lisan dan tulisan apabila melakukan kesalahan, banyak pegawai dalam mengerjakan pekerjaan tidak tepat waktu $(66,7 \%)$ serta $60 \%$ responden menyatakan bahwa pegawai kurang bersikap santun terhadap sesama rekan kerja.

Berdasarkan latar belakang dan hasil prasurvey pada Kantor Dinas Pekerjaan Umum dan Penataan Ruang di kabupaten Dharmasraya ditemukan beberapa permasalahan yang perlu untuk diteliti. Variabel yang ingin diteliti adalah Sanksi, Reward, Pengembangan Sumber Daya Manusia dan Disiplin.

Adapun rumusan masalah yang dikemukakan oleh peneliti sebagai berikut: 1.Apakah Sanksi berpengaruh terhadap disiplin kerja pegawai pada Kantor Dinas Pekerjaan Umum dan Penataan Ruang di Kabupaten Dharmasraya? 2.Apakah reward berpengaruh terhadap disiplin kerja pegawai pada Kantor Dinas Pekerjaan Umum dan Penataan Ruang di Kabupaten Dharmasraya? 3.Apakah pengembangan sumber daya manusia berpengaruh terhadap disiplin kerja pegawai pada Dinas Pekerjaan Umum dan Penataan Ruang di Kabupaten Dharmasraya?

\section{KAJIAN TEORI}

\section{Pengertian Disiplin Kerja}

Menurut Anoraga (2006;46) disiplin dalam bahasa indonesia susunan W.J.S.Poerwadarminta adalah latihan batin dan watak dengan maksud supaya segala perbuatannya selalu mentaati tata tertib dan ketaatan pada aturan dan tata tertib.

Menurut Siagian, (2001:304) disiplin yang baik mencerminkan besarnya rasa tanggung jawab seseorang terhadap tugas- tugas yang diberikan kepadanya. Hal ini mendorong gairah kerja, semangat kerja, dan terwujudnya tujuan perusahaan, karyawan dan masyarakat. Oleh karena itu, setiap manajer selalu berusaha agar para bawahannya mempunyai disiplin 
yang baik, Disiplin pegawai adalah suatu bentuk pelatihan yang berusaha memperbaiki dan membentuk pengetahuan, sikap dan perilaku karyawan sehingga pada karyawan para karyawan tersebut secara sukarela berusaha bekerja secara kooperatif dengan para karyawan yang lain serta meningkatkan prestasi kerja

Berdasarkan pendapat-pendapat diatas dapat disimpulkan bahwa disiplin adalah suatu bentuk kegiatan yang dilakukan oleh manajemen baik perusahaan, instansi pemerintah ataupun swasta agar pegawai dapat bekerja sesuai dengan ketentuan yang berlaku sehingga kinerja mereka sesuai dengan yang diharapkan dan bias mencapai tujuan dari perusahaan.

\section{Pengertian Sanksi}

Menurut Satrohadiwiryo (2003:293) Tujuan utama mengadakan sanksi disiplin kerja bagi pegawai yang melanggar norma-norma perubahan adalah memperbaiki dan mendidik para pegawai yang melakukan pelanggaran disiplin. Sanksi atas pelanggaran disiplin yang dijatuhkan harusnya setimpal dengan pelanggaran disiplin yang dilakukan sehingga secara adil dapat diterima.

Sanksi indisipliner dilakukan untuk mengarahkan dan memperbaiki perilaku karyawan dan bukan untuk menyakiti. Tindakan disipliner hanya dilakukan pada pegawai yang tidak dapat mematuhi peraturan atau prosedur organisasi. Melemahnya disiplin kerja akan mempengaruhi moral karyawan secara langsung, oleh karena itu tindakan koreksi dan pencegahan terhadap melemahnya peraturan harus segera diatasi oleh semua komponen yang terlibat dalam organisasi.

\section{Pengertian Reward}

Reward merupakan salah satu metode untuk memotivasi seseorang untuk melakukan kebaikan dan meningkatkan prestasinmya Dalam organisasi, suatu penghargaan dalam bentuk material atau non material yang diberikan oleh pihak pimpinan organisasi perusahaankepada karyawan bertujuan agar memotivasi mereka bekerja lebih keras dan berprestasi dalam mencapai tujuan-tujuan perusahaan atau organisasi (Syarifah dkk, 2013:163).

Menurut Eugene dan Nic (2004:162) Evaluasi pekerjaan dapat didiskripsikan sebagai proses yang digunakan pada level perusahaan atau industri untuk menemukan hubungan antarpekerjaan dan untuk menentukan struktur tingkat upah sistematis bagi berbagai pekerjaan.

\section{Pengertian Pengembangan Sumber Daya Manusia}

Menurut Malayu Hasibuan (2009) Manajemen adalah ilmu dan seni mengatur proses pemanfaatan sumber daya manusia dan sumber-sumber daya lainnya secara efektif dan efisien untuk mencapai suatu tujuan tertentu.

Sumber daya manusia merupakan salah satu modal utama dalam sebuah organisasi.Ketika dihadapkan pada peningkatan disiplin kerja pegawai, maka peningkatan sumber daya manusia harus menjadi salah satu agenda pokok dalam penataan organisasi.

Manajemen sumber daya manusia terdiri dari empat suku kata, yaitu manajemen, sumber, daya dan manusia. Keempat suku kata terbukti tidak sulit untuk dipahami artinya. Sumber daya manusia sering disebut sebagai 
Human Resource, tenaga atau kekuatan manusia (energy atau power). Sumber daya yang juga disebut sumber tenaga, kemampuan, kekuatan, keahlian yang dimiliki oleh manusia, dipunyai juga oleh makhluk organisasi lainnya, Notoatmojo, (2003).

Menurut Hasibuan (2009:10) manajemen sumber daya manusia lebih memfokuskan pembahasannya mengenai pengaturan peranan manusia dalam mewujudkan tujuan yang optimal. Pengaturan ini meliputi masalah perencanaan (Human Resources Planning), pengorganisasian, pengarahan, pengendalian, pengadaan, pengembangan, kompensasi, pengintegrasian, pemeliharaan, kedisiplinan, dan pemberhentian tenaga kerja untuk membantu terwujudnya tujuan peusahaan, karyawan dan masyarakat.

Keterampilan pegawai, merupakan salah satu faktor utama dalam usaha mencapai tujuan organisasi. Bagi karyawan-karyawan baru ataupun karyawan-karyawan yang menghadapi pekerjaan baru, diperlukan adanya tambahan ketrampilan guna melaksanakan tugasnya dengan baik.

Pengetahuan dan keterampilan saja belum cukup menjamin suksesnya pencapaian tujuan. Sikap karyawan terhadap pelaksanaan tugas, juga merupakan faktor kunci dalam mencapai sukses. Oleh karena itu pengembangan sikap juga harus diusahakan dalam pengembangan karyawan.

\section{Hipotesis}

Berdasarkan pada uraian kerangka konseptual di atas dan untuk menjawab identifikasi masalah, maka penulis dapat merumuskan suatu hipotesis yaitu : H1: Diduga sanksi berpengaruh positif dan sinigfikan terhadap disiplin kerja pegawai pada kantor Dinas Pekerjaan Umum dan Penataan Ruang Kabupaten Dharmasraya.

H2: Diduga reward berpengaruh positif dan signifikan terhadap disiplin kerja pegawai pada Kantor Dinas Pekerjaan Umum dan Penataan Ruang di Kabupaten Dharmasraya.

H3: Diduga pengembangan sumber daya manusia berpengaruh positif dan signifikan terhadap disiplin kerja pegawai pada Kantor Dinas Pekerjaan Umum dan Penataan Ruang di Kabupaten Dharmasraya.

\section{METODE PENELITIAN}

\section{Jenis Penelitian}

Jenis penelitian yang digunakan dalam penelitian ini adalah penelitian kuantitatif. Menurut Sugiyono (2014) penelitian kuantitatif adalah suatu metode penelitian yang bersifat induktif, objektif dan ilmiah di mana data yang di peroleh berupa angka-angka (score, nilai) atau pernyataanpernyataan yang di nilai, dan dianalisis dengan analisis statistik. Penelitian Kuantitatif biasanya di gunakan untuk membuktikan dan menolak suatu teori. Karena penelitian ini biasanya bertolak dari suatu teori yang kemudian di teliti, di hasilkan data, kemudian di bahas dan di ambil kesimpulannya. 


\section{Objek Penelitian}

Objek penelitian yang akan dilakukan oleh peneliti yaitu pada karyawan Kantor Dinas Pekerjaan Umum dan Penataan Ruang Kabupaten Dharmasraya.

\section{Populasi dan Sampel}

Populasi dari penelitian ini adalah karyawan Dinas Pekerjaan Umum dan Penataan Ruang Kabupaten Dharmasraya sebanyak 152 orang yang terdiri dari Enam Bidang yaitu bidang Upt Alkal terdiri dari 65 orang , Bidang Sekreteriat terdiri dari 19 Orang,Bidang Pengairan terdiri dari 22 Orang,Bidang Bina Marga terdiri dari 19 Orang, Bidang Cipta Karya terdiri dari 19 Orang dan Bidang Tata Ruang 9 Orang.

Untuk mengetahui besarnya sampel penelitian maka digunakan teknik pengambilan sampel dengan cara sampling kuota seperti yang dikemukakan Riduwan dan Akdon (2006) yaitu teknik penentuan sampel dari populasi yang mempunyai ciri-ciri tertentu sampai jumlah yang dikehendaki atau pengambilan sampel yang didasarkan pada pertimbangan tertentu dari peneliti. Untuk mengetahui besarnya sampel penelitian menggunakan rumus dari Taro Yamane atau Slovin seperti yang dikemukakan Riduwan dan Akdon (2006), Sehingga besarnya sampel penelitian yang digunakan adalah 110 orang.

\section{ANALISA DAN PEMBAHASAN}

\section{Gambaran Umum Objek Penelitian}

Responden dalam penelitian ini adalah pegawai Dinas Pekerjaan Umum dan Penataan Ruangan Kabupaten Dharmasraya yang terdiri dari berbagai bidang yaitu; bidang cipta karya, bidang bina marga, bidang pengairan, bidang tata ruang, sekeretariat, dan UPT Alkal. Semua kuesioner yang akan disebar sebanyak 110 kuesioner kepada seluruh bidang yang bersangkutan dan kuesioner diberikan secara langsung kepada responden. Pengambilan kuisoner dijemput langsung setelah responden yang bersangkutan mengisi kuisioner.

Dari total kuesioner yang disebarkan yakni 110 buah, hanya 85 kuesioner yang dapat diolah Pada penelitian ini juga terdapat beberapa kuisioner yang tidak dapat diolah disebabkan karena tidak lengkapnya pengisian kuisoner oleh responden.kendala yang menyebabkan berkurangnya tingkat pengembalian kuesioner adalah karena adanya beberapa dari responden yang sedang tidak berada ditempat atau tugas luar kota dan juga tidak mengisi kuisioner dengan alasan sibuk.

\section{Demografi Responden}

Demografi responden terbagi menjadi 4 karakteristik yang mana dijelaskan sebagai berikut: Berdasarkan data table 4.2 tentang karakteristik status pernikahan dapat dilihat bahwa yang berstatus menikah adalah 74 atau $87,1 \%$ dari yang belum menikah 11 atau $12,9 \%$. Data tersebut dapat disimpulkan bahwa yang dominan dalam penelitian adalah yang sudah menikah 
Berdasarkan data table 4.3 tentang karakteristik umur dapat dilihat bahwa yang berumur 31-35 adalah sampel terbanyak dalam penelitian ini dilihat dari 35 atau 41,2\% responden. Sedangkan umur dari 26-30 dan 31-35 memiliki responden sama dengan 18 atau $12,2 \%$ dan untuk umur $>41$ memiliki responden 14 atau $16,5 \%$

Berdasarkan data table 4.3 tentang karakteristik pendidikan dapat dilihat bahwa pegawai masih ada yang berpendidikan SMP yang mana jumlah respondennya 3 atau 3,5\% sedangkan SMA jumlah respondennya 50 atau $58,8 \%$ dan D3/S1 sebanyak 32 atau 37,6\%. Dari data tersebut dapat disimpulkan bahwa adanya pegawai yang berpendidikan SMP dan di dominasi oleh yang berpendidikan SMA.

Berdasarkan data tentang karakteristik masa kerja dapat dilihat bahwa masa kerja yang terbanyak terdapata pada range 6-10 tahun yang mana jumlah respondenya adalah 40 atau $47,06 \%$ menyusul dengan masa kerja $>10$ sebanyak 27 atau 31,77\% dan untuk masa kerja 1-5 tahun diperoleh responden sebanyak 18 atau $21,17 \%$.

\section{HASIL PENELITIAN}

\section{Uji Normalitas}

Dari Tabel 4.18, terlihat bahwa nilai asymp.sig (2-tailed) menunjukkan nilai > dari 0.05 , yaitu 0.846 Dengan demikian data dapat dikatakan berdistribusi normal.

2. Uji Multikolinearitas

Untuk menguji adanya multikolinearitas dapat dilihat melalui Variance Inflantion Factor (VIF) $<10$ dan tolerance $>0.1$. Variabel sanksi (X1) dengan nilai VIF 1.276, variabel reward (X2) dengan nilai VIF 1.276, dan variabel pengembangan sumber daya manusia (X3) dengan nilai VIF 1.000. Pada variabel sanksi (X1) dengan nilai tolerance 0,784, variabel reward (X2) dengan nilai tolerance 0,784 , dan variabel pengembangan sumber daya manusia (X3) dengan nilai tolerance 1,000. Dengan demikian dapat dikatakan bahwa tidak terdapat korelasi variabel-variabel bebas antara satu dengan yang lainnya, atau variabel independent pada penelitian ini bebas multikolineritas.

4. Uji Heteroskedastisitas

Berdasarkan output Scatterplots pada gambar 4.1 maka dapat diketahui bahwa;

1. Titik-titik data menyebar diatas dan dibawah atau disekitar angka 0

2. Titik-titik tidak mengumpul hanya diatas atau dibawah saja

3. Penyebaran Titik data tidak membentuk pola yang jelas.

Berdasarkan penjelasan diatas maka dapat dinyatakan bahwa uji heteroskedastisitas tidak mempunyai masalah.

5. Analisis Regresi Berganda

Tabel diatas dapat disubstitusikan ke dalam model estimasi sebagai berikut :

$\mathrm{Y}=24.705+1,509 \mathrm{X} 1+0,546 \mathrm{X} 2-0,393 \mathrm{X} 3$ 
Dari persamaan diatas dapat dilihat bahwa terdapat nilai konstanta sebesar 24,705 yang berarti bahwa tanpa ada sanksi, reward dan pengembangan sumber daya manusia terhadap disiplin kerja pegawai berada pada 24,705 satuan. Nilai koefisien dari variabel X1 adalah sebesar 1,509 ini berarti bahwa pemberian sanksi pada satu satuan, maka akan meningkatkan disiplin kerja pegawai sebesar 1,509. Nilai koefisien X2 adalah sebesar 0,546 ini berarti bahwa dengan pemberian reward pada satu satuan maka akan meningkatkan disiplin kerja pegawai sebesar 0,546 satuan. Nilai koefisien dari variabel X3 adalah sebesar -0,393 ini berarti bahwa meningkatnya pengembangan sumber daya manusai satu satuan, maka akan meningkatkan disiplin kerja pegawai sebesar -0,393 satuan.

\section{Uji F}

Tabel 4.21 Pengaruh secara bersama sama variabel independen terhadap variabel dependen dilakukan dengan cara membandingkan $\mathrm{F}$ tabel dan $\mathrm{F}$ hitung. Hipotesis diterima jika $\mathrm{F}$ hitung $>\mathrm{F}$ tabel dan nilai sig $<\alpha 0,05$. Nilai $F$ tabel pada $\alpha 0,05$ adalah 2,72. Nilai $F$ hitung adalah 18,863 sedangkan nilai sig adalah 0,000 . Dengan demikian berarti $\mathrm{F}$ hitung $>\mathrm{F}$ tabel dan nilai sig $<\alpha 0,05$, yaitu $18,297>2,72$, dan sig $0,000<\alpha 0,05$. Hal ini menunjukkan bahwa model regresi dapat digunakan untuk menguji pengaruh secara bersama-sama variabel independen terhadap variabel dependen, yaitu sanksi, reward, dan pengembangan sumber daya manusia secara bersama-sama berpengaruh terhadap disiplin kerja pegawai.

7. Uji T

a. Pengujian Hipotesis 1

Pengujian hipotesis 1 dilakukan dengan membandingkan nilai t hitung dan $\mathrm{t}$ tabel. Hipotesis diterima jika $\mathrm{t}$ hitung $>\mathrm{t}$ tabel atau nilai sig $<\alpha$ 0,05 . Nilai t tabel pada $\alpha=0,05$ adalah 1,6638 . Untuk variabel sanksi (X1) nilai t hitung adalah 5,051 atau nilai sig adalah 0,000. Dengan demikian dapat dikatakan bahwa t hitung $>\mathrm{t}$ tabel, yaitu 5,051 >1,6638 atau nilai signifikansi $0,000<\alpha 0,05$. Nilai koefisien $\beta$ dari variabel X1 bernilai positif yaitu 1,059 . Hal ini menunjukkan bahwa penelitian ini dapat membuktikan sanksi (X1) berpengaruh signifikan dan positif terhadap disiplin kerja pegawai. Sehingga hipotesis pertama pada penelitian ini dapat diterima

\section{b. Pengujian Hipotesis 2}

Pengujian hipotesis 2 dilakukan dengan membandingkan nilai thitung dan $\mathrm{t}$ tabel. Hipotesis diterima jika $\mathrm{t}$ hitung $>\mathrm{t}$ tabel atau nilai sig $<\alpha$ 0,05 . Nilai t tabel pada $\alpha=0,05$ adalah 1,6638 . Untuk variabel reward (X2) nilai t hitung adalah 2,421 atau nilai sig adalah 0,018. Dengan demikian dapat dikatakan bahwa $\mathrm{t}$ hitung $>\mathrm{t}$ tabel, yaitu 2,241 > 1,6638 atau nilai signifikansi $0,018<\alpha 0,05$. Nilai koefisien $\beta$ dari variabel X2 bernilai positif yaitu 0,546. Hal ini menunjukkan bahwa penelitian ini dapat membuktikan reward (X2) berpengaruh signifikan dan positif terhadap disiplin kerja pegawai. Sehingga hipotesis pertama pada penelitian ini dapat diterima

3. Pengujian Hipotesis 3 
Pengujian hipotesis 3 dilakukan dengan membandingkan nilai $\mathrm{t}$ hitung dan $\mathrm{t}$ tabel. Hipotesis diterima jika $\mathrm{t}$ hitung $>\mathrm{t}$ tabel atau nilai sig $<\alpha 0,05$. Nilai t tabel pada $\alpha=0,05$ adalah 1,6638 . Untuk variabel pengembangan sumber daya manusia (X3) nilai t hitung adalah $-1,728$ atau nilai sig adalah 0,088. Dengan demikian dapat dikatakan bahwa t hitung $<\mathrm{t}$ tabel, yaitu $-1,728<1,6638$ atau nilai signifikansi $0,88>\alpha 0,05$. Nilai koefisien $\beta$ dari variabel X3 bernilai negatif yaitu $-0,393$. Hal ini menunjukkan bahwa penelitian ini dapat membuktikan pengembangan sumber daya manusia (X3) tidak berpengaruh signifikan dan negatif terhadap disiplin kerja pegawai. Sehingga hipotesis ketiga pada penelitian ini tidak dapat diterima

\section{Koefisien Determinasi}

Nilai Adjusted R square menunjukkan 0,389. Hal ini mengindikasikan bahwa kontribusi variabel bebas yaitu sanksi, reward dan pengembangan sumber daya manusia terhadap variabel terikat yaitu disiplin kerja pegawai $38,9 \%$, sedangkan $61,1 \%$ ditentukan oleh faktor lain.

\section{PEMBAHASAN}

Hasil dari penelitian bahwa sanksi berpengaruh positif terhadap disiplin kerja pegawai. Ini dilihat berdasarkan hasil statistic yang ditemukan bahwa hipotesis pertama (H1) disimpulkan bahwa sanksi mempunyai pengaruh yang signifikan dan positif terhadap disiplin kerja pegawai. Hal ini dapat dilihat dari nilai signifikansinya yaitu 0,000 (kecil dari $\alpha=0,05$ ). Dari analisis regresi berganda terlihat bahwa dalam memberikan sanksi kepada disiplin dengan baik dan konsisten maka disiplin kerja pegawai akan terus meningkat. Ini berarti bahwa hubungan antara sanksi serarah dengan disiplin kerja pegawai. Semakin baik dalam menerapkan sanksi maka semakin baik pula peningkatan disiplin pegawai.

Berdasarkan hasil analisis statistik dalam penelitian ini ditemukan bahwa hipotesis kedua (H2) disimpulkan bahwa reward mempunyai pengaruh signifikan dan positif terhadap. Hal ini dapat dilihat dari nilai signifikansinya yaitu 0,018 (kecil dari $\alpha=0,05$ ). Dari analisis regresi berganda terlihat bahwa pemberian reward dengan tepat kepada pegawai yang menerapkan disiplin maka akan meningkatkan kedisiplinan pegawai. Ini berarti bahwa hubungan antara reward serarah dengan disiplin kerja pegawai. Semakin banyak memberikan reward kepada pegawai yang disipliner maka semakin meningkatnya disiplin kerja pegawai yang disipliner

Berdasarkan hasil analisis statistik dalam penelitian ini ditemukan bahwa hipotesis ketiga (H3) disimpulkan bahwa pengembangan sumber daya manusia tidak mempunyai pengaruh signifikan dan negatif terhadap disiplin kerja pegawai. Hal ini dapat dilihat dari nilai signifikansinya yaitu 0,088 (besar dari $\alpha=0,05$ ). Dari analisis regresi berganda terlihat bahwa pengembangan sumber daya manusia tidak akan mempengaruhi disiplin 
kerja pegawai. Ini berarti bahwa hubungan antara pengembangan sumber daya manusia tidak serarah dengan disiplin kerja pegawai.

\section{KESIMPULAN DAN SARAN}

\section{Kesimpulan}

Kesimpulan yang dapat diambil dari pengaruh sanksi, reward, dan pengembangan sumber daya manusia terhadap disiplin kerja pegawai yang dilakukan di Dinas Pekerjaan Umum dan Penataan Ruang Kabupaten Dharmasraya adalah sebagai berikut:

1. Sanksi yang diberikan kepada indisipliner berpengaruh positif dan signifikan terhadap disiplin kerja pegawai yang mana dapat dilihat pada nilai t hitung > t tabel, yaitu 5,051 > 1,6638 atau nilai signifikansi 0,000 $<\alpha 0,05$. Nilai koefisien $\beta$ dari variabel sanksi (X1) bernilai positif yaitu 1,059 .

2. Reward yang diberikan kepada disipliner berpengaruh positif signifikan terhadap disiplin kerja pegawai yang mana dapat dilihat pada nilai $\mathrm{t}$ hitung $>\mathrm{t}$ tabel, yaitu 2,241 $>1,6638$ atau nilai signifikansi $0,018<\alpha$ 0,05 . Nilai koefisien $\beta$ dari variabel X2 bernilai positif yaitu 0,546 .

3. Pengembangan sumber daya manusia kepada pelaku disiplin tidak berpengaruh signifikan dan negatif terhadap perilaku disiplin kerja pegawai yang mana dapat dilihat pada nilai bahwa $t$ hitung $<\mathrm{t}$ tabel, yaitu $-1,728<1,6638$ atau nilai signifikansi $0,88>\alpha 0,05$. Nilai koefisien $\beta$ dari variabel X3 bernilai negatif yaitu $-0,393$. Mungkin ini disebabkan karena tidak adanya saling keterkaitan antara pengembangan sumber daya manusia dengan disiplin kerja pegawai.

2. Saran

Berdasarkan hasil penelitian yang telah dilakukan, ada beberapa saran yang dapat dipertimbangkan oleh berbagai pihak:

1. Bagi instansi pemerintah diharapkan pemberian sanksi kepada pelaku indisipliner harus dilaksanakan secara bijak dan konsisten sehingga pelaku indisipliner akan merubah tingkah lakunya. Sedangkan untuk pemberian reward kepada pelaku disipliner agar sesuai dengan disiplin dan kinerja yang dilakukan oleh disipliner. Maka pimpinan dalam sebuah instansi harus memberikan teladan yang baik kepada bawahannya.

2. Pada peneliti berikutnya supaya dapat melengkapi metode survei penelitian ini dengan wawancara karena saat melakukan penelitian ini peneliti sempat mewawancarai beberapa responden dan menemukan adanya perbedaan antara jawaban di kusioner dan jawaban secara lisan untuk pertanyaan/ pernyataan yang sama, dan peneliti berikutnya juga dapat mempertimbangkan untuk menambahkan variabel-variabel lain yang diduga berpengaruh terhadap disiplin kerja pegawai. 


\section{DAFTAR PUSTAKA}

A. Prihantoro, "Peningkatan Kinerja Sumber Daya Manusia Melalui Motivasi, Disiplin, Lingkungan Kerja, Dan Komitmen," jurnal Value Added, vol. 8, no. 2, pp. 78-98, 2012.

Achmad Slamet, 2007, Manajemen Sumber Daya Manusia, Unnes Press, Semarang.

Agung Nugroho, 2005. Strategi Jitu memilih Metode statistic Penelitian dengan. SPSS, Andi Jogyakarta.

Akdon, Riduwan. 2006. Rumus dan Data dalam Aplikasi Statistika. Cetakan I. Bandung : Alfabeta.

Anoraga, Pandji. (2006). Psikologi Kerja. Jakarta: PT. Rineka Cipta.

Arikunto, S. 2012. Prosedur Penelitian: Suatu Pendekatan Praktek. Jakarta: Rineka Cipta

Aziz, N. (2019). Pengaruh Lingkungan Kerja Terhadap Kinerja Yang Dimediasi Oleh Motivasi Kerja Karyawan Rocky Plaza Hotel Padang. https://doi.org/10.17605/OSF.IO/E4C59

B. Siswanto Sastrohadiwiryo, DR, (2003), Manajemen Tenaga Kerja Indonesia, edisi 2, PT. Bumi Aksara, Jakarta.

David L. Goetsch dan Stanley B. Davis. (2002). Pengantar Manajemen Mutu 2,. Ed. Bahasa Indonesia, Jakarta: PT Prenhalindo.

Edirisooriya, Waruni Ayesha (2014)," Impact of Rewards on Employee Performance: With Special Reference to ElectriCo", ICME, Proceedings of the 3rd International Conference on Management and Economics, Faculty of Management and Finance, University of Ruhuna, Sri Lanka, Page 13

Ghozali, Imam. (2011). Aplikasi Analisis Multivariate Dengan Program IBM. SPSS 19 (edisi kelima.) Semarang: Universitas Diponegoro.

Ghozali, Imam. 2006. Aplikasi Analisis Multivariate dengan Program SPSS. (Edisi Ke 4). Semarang:Badan Penerbit Universitas Diponegoro.

Hadi, Sutrisno. 2004. Metodologi Research Jilid 3. Yogyakarta : Andi.

Handoko, T Hani. 2001. Manajemen Personalia dan Sumberdaya Manusia,Edisi. Kedua. BPFE, Yogyakarta. 
Hasibuan, Malayu S.P. 2009. Manajemen: Dasar, Pengertian, dan Masalah. Edisi Revisi. Jakarta : Bumi Aksara.

Henry Simamora. 2004. Manajemen Sumber Daya Manusia. Edisi Ke-3. STIE YKPN. Yogyakarta.

K. Kabupaten, K. Timur, and K. Timur, "Pengaruh Reward Dan Punishment Terhadap Kinerja Pegawai Di Dinas Pendidikan Dan Kebudayaan Kabupaten Kutai Timur Ruslan Mas ' ud, LCA . Robin Jonathan , Elfreda Aplonia Lau," 1945.

Lubis, A. Y. O., \& Susanti, F. (2019). Pengaruh Gaya Kepemimpinan Dan Kompensasi Terhadap Prestasi Kerja Karyawan (Studi pada PT Japfa Comfeed Indonesia (JCI) Tbk Devisi Fam 1. https://doi.org/10.31227/osf.io/7tbrg

Mayliza, R. (2019). Pengaruh Gaya Kepemimpinan Dan Disiplin Kerja Terhadap Kinerja Karyawan Dengan Motivasi Kerja Sebagai Variabel Intervening Pada PT. Semen Padang. https://doi.org/10.17605/OSF.IO/FYPQ9.

Mayliza, R. (2019). Pengaruh Gaya Kepemimpinan Dan Disiplin Kerja Terhadap Kinerja Pegawai, Dengan Motivasi Kerja Sebagai Variabel Intervening (Studi Pada Dinas Pendidikan Kabupaten Tanah Datar). https://doi.org/10.17605/OSF.IO/JGPDN

Miftah Thoha. (2005). Perilaku Organisasi Konsep Dasar Dan Aplikasi. Jakarta:PT.Raja Grafindo Persada

Notoatmodjo, Soekidjo. 2003. Pengembangan Sumber Daya Manusia. Rineka. Cipta. Jakarta.

Rivai, Veithzal dan Ella Jauvani Sagala, 2014. Manajemen Sumber Daya Manusia untuk Perusahaan. Edisi Kedua, Jakarta. Raja Grafindo Persada,

Sondang P. Siagian, 2001, Manajemen Sumber Daya Manusia, Bumi Aksara, Jakarta.

Sondang P. Siagian, 2001, Manajemen Sumber Daya Manusia, Bumi Aksara, Jakarta

Sugiarto. 2003. Teknik Sampling. Jakarta. PT. Gramedia Pustaka Utama.

Sugiyono. (2005) Metode Penelitian Kuantitatif Kualitatif dan $R \& D$. 
Bandung : Alfabeta.

Sugiyono. (2014) Metode Penelitian Kuantitatif Kualitatif dan R\&D. Bandung : Alfabeta.

Syarifah dkk, 2013. Pengaruh Gaya Kepemimpinan, Komitmen Organisasi, Kualitas Sumber Daya, Reward, dan Punishment Terhadap Anggaran Berbasis Kinerja. Malang

Teguh Sriwidadi, Oey Charlie (2011). Analisis Pengaruh Gaya Kepemimpinan Terhadap Kinerja SPG PD. Sumber Jaya. Business Review Vol 2. No.1, Mei 2011, 387-398 